\title{
Moving Beyond English as a Requirement to "Fit In": Considering Refugee and Migrant Education in South Australia
}

\author{
Clemence Due and Damien Riggs
}

\begin{abstract}
This paper presents findings from research conducted in two primary schools in South Australia with New Arrivals Programs (NAPs). The paper draws upon two forms of data: questionnaires administered to teachers and ethnographic observations of children at play in the schoolyard. These data are used to examine two aspects of education for refugees and other migrants: (1) the assumption that English language acquisition is central to the "integration" of refugees and other newly arrived migrants (and both that integration is of key importance and that the work of integration must primarily be undertaken by refugees and other migrants, not the broader community); and (2) the impact of power differentials between NAP and nonNAP students in the use of playground spaces. We argue that the education provided to refugee and newly arrived migrant students in NAPs needs to move beyond treating English language acquisition as a requirement to "fit in," and we call for schools with high populations of refugee and migrant students to consider how spatial relations in their schools may be negatively impacting these student populations. Finally, the paper calls for an approach to education that is situated in global contexts of colonization and power relations, and in which the terms for inclusion of NAP students are mutually negotiated, rather than predetermined.
\end{abstract}

\section{Résumé}

Cet article présente les résultats de la recherche menée dans deux écoles primaires en Australie-Méridionale offrant des programmes pour nouveaux arrivants (New Arrivals Programs). La recherche s'appuie sur deux types de données : questionnaires administrés aux enseignants et observations ethnographiques des enfants au jeu dans la cour d'école. Ces données sont utilisées pour examiner deux aspects de l'éducation pour réfugiés et autres migrants : 1) l'hypothèse voulant que l'acquisition de la langue anglaise est au coeur de "l'intégration" des réfugiés et autres nouveaux arrivants (et à la fois que l'intégration est d'une importance capitale et que le travail d'intégration doit se faire prioritairement par les réfugiés et autres migrants, et non l'ensemble de la communauté); 2) l'impact des écarts de pouvoir entre les nouveaux arrivants et les autres écoliers dans l'utilisation des espaces de jeux. Les auteurs soutiennent que l'enseignement dispensé aux écoliers réfugiés et nouvellement arrivés dans le cadre des programmes pour nouveaux arrivants doit aller au-delà du traitement de l'acquisition de la langue anglaise comme nécessaire à l'«intégration", et demandent aux écoles ayant de fortes populations d'écoliers réfugiés et migrants d'examiner comment les relations spatiales au sein de l'école peuvent avoir un impact négatif sur ces populations. Enfin, les auteurs favorisent une approche éducative située dans les contextes mondiaux de la colonisation et des relations de pouvoir dans laquelle les conditions d'intégration des écoliers nouvellement arrivés sont mutuellement négociées, plutôt que prédéterminées.

\section{Introduction}

In Australia in 2009 there was a significant increase in the number of asylum seekers arriving within Australian waters attempting to claim refuge. Whilst this increased movement of people across borders was thought to primarily be the result of much greater numbers of people being displaced from their countries of origin than in previous years, ${ }^{1}$ the Australian media and government suggested instead that people were arriving due to a softening of Australia's border security policies, ${ }^{2}$ despite the fact that Australia spends millions of dollars per year on strategies to prevent asylum seekers arriving unexpectedly by boat (even though the 
number of people arriving this way usually only amounts to several hundred per year). ${ }^{3}$ Indeed, largely as a result of government and media rhetoric relating to "border security" (and its definitions of who is allowed to enter the country and on what terms), asylum seekers who arrive other than through "official" channels are widely depicted as "queue jumpers" or "illegals," 4 in Australia. Furthermore, these asylum seekers are treated in a punitive fashion involving mandatory detention (which until recently included children), regardless of whether or not they are subsequently granted refugee status. ${ }^{5}$

Given the above context facing people seeking asylum in Australia, it is fair to state that experiences of forced migration to the country are as much shaped by the experience of borders enforced within Australia as they are by the effects of displacement. ${ }^{6}$ In other words, and as Cole argues, the history of immigration (and specifically forced migration) has been one of "institutionalized racism at the border," 7 which is fundamentally in opposition to liberal political theories, in that restrictive border control effectively penalizes people for circumstances beyond their control. By contrast, advocates for a No Borders approach, as elaborated throughout this issue of Refuge, argue that embracing movements of people in the same way that the globalized world currently embraces the free movement of goods would help to eliminate such persecution and racism. ${ }^{8}$ At present in Australia, however, it is precisely debates about "losing control" of the border that function to engender fears of invasion by "hordes" of refugees, ${ }^{9}$ thus reinforcing negative sentiment towards refugees as being Other to Australia.

As stated above, the negative sentiment pervasively seen in the Australian media and other institutions is primarily targeted towards those arriving in Australia "unexpectedly," outside "official" channels. However, and in many instances, this negative sentiment is extended to all refugees arriving in Australia, thus making it difficult for people who arrive on humanitarian visas to settle in Australia and the communities into which they are placed. Similar difficulties are encountered by planned migrants considered either of "middle-eastern appearance" 10 or "Third-World looking"11_categories into which the majority of NAP students observed as part of this study would certainly be simplistically identified by many as falling. These difficulties are arguably compounded by the fact that refugees who are granted visas and placed in communities may still experience high levels of racism and xenophobia, often based on a perceived failure on the part of refugees and other migrants to adhere to "Australian values and culture." 12 As such, the onus is generally placed upon refugees and newly arrived migrants to undertake the bridge-building work of engaging with current Australian citizens, rather than the community into which refugees are placed accepting some responsibility for developing strategies to bridge divisions which may exist between all communities. ${ }^{13}$

Yet despite this negative reality faced by refugees and other newly arrived migrants, Australia is still widely conceptualized as "generous" in its approach to "inclusion."14 Such a paternalistic understanding allows Australia to ignore both its own colonial history (and the status of nonindigenous people as ourselves migrants in illegal possession of land), and also the location of Australia within a global colonial history that continues to produce the disparities we see between developed and "Third-World" nations. ${ }^{15}$ Focusing on procedural, rather than relational, understandings of forced migration thus allows Australia to be positioned largely outside the complex colonial histories of which it is an active part, and through which it may be suggested the process of forced migration is produced. ${ }^{16}$ Indeed, in order to fully understand a politics of No Borders it is essential to adopt a relational understanding of migration which considers the responsibilities Australia has as an industrialized country. For example, as a member state within the Commonwealth, Australia is complicit in colonizing practices that have affected large areas of Africa. Such responsibilities may become even more evident as the effects of this industrialization bear upon developing countries, for example through the effects of climate change.

Of course not all Australian citizens will take up unquestioningly the negative messages about refugees and migration we outline above. However it is likely to be the case that many will, particularly given the unease often expressed in Australia regarding the fact that refugee protection is established by international law, and thus may impact upon desired national laws, particularly those regarding closed and tightly regulated borders for human migration purposes. ${ }^{17}$ Thus it is important for us to consider the implications of these pervasive negative representations for both refugees (and other migrants) themselves, and for those who may work with these populations in situations not necessarily of their choosing. One such instance where this can be examined, and as is our focus within this paper, is in schools that include a New Arrivals Program (NAP) into which both immigrants, and those refugees recognized as "genuine" and correspondingly granted a visa, enter once they arrive in Australia. More specifically, this paper considers research undertaken in two South Australian primary schools with NAPs and examines two major elements identified in both the project being presented here, and in previous literature relating to refugee education. These are: the widespread assumption of the 
impact of low levels of English language skills on refugee and migrant "integration," and the ways in which the uses of space within schools effect NAP students and their ability to claim spaces as their own.

Importantly, it must be noted that whilst much of our emphasis thus far has been upon depictions and treatment of refugees in Australia, not all NAP students are refugees. At the two schools in which we conducted research, refugees accounted for approximately 30 per cent of the NAP student population. However, and as we noted above, negative sentiment about "illegal" refugees and the expectation of adherence to "Australian values" extends to all migrants from non-English-speaking background countries, especially those who are not identified as white.

\section{The Study}

The study took place in two primary schools located in South Australia over a period of eight weeks. These schools represent two of the sixteen South Australian schools that include a New Arrivals Program. In order to preserve the anonymity of the schools, they are referred to throughout as Hills Primary School (HPS) and Plains Primary School (PPS). HPS had a total of 222 students at the time the research took place, with 75 NAP students spread across six NAP classes. As such, NAP students accounted for 34 per cent of the student body at the school. Of the NAP students 29 (39 per cent) were refugees. HPS was rated as a category 6 school on the Department of Education and Children's Services (DECS) Index of Educational Disadvantage, where a category 1 school serves students from the most disadvantaged families, and a category 7 school serves students from the least disadvantaged families.

PPS, in contrast, is a category 3 school. PPS had a larger number of students (294), but is situated on a smaller amount of land, with a smaller playground space. The school has almost the same number of NAP students (70), spread over five different classes. NAP students comprise around 24 per cent of the student population. Of the NAP students enrolled in the school at the time the research took place, 18 were refugees ( 25 per cent).

\section{Data Collection}

Initially, ethics approval was granted by both the Department of Education and Children's Services (DECS) and the authors' university. Consultation meetings were then held with both schools identified as key sites for the study by DECS. Both schools expressed enthusiasm at being involved in the project. Information sheets were provided to the schools for parents to inform them of the study and the minimal impact it would have upon students in their everyday schooling.
The study involved several forms of data collection. First, an ethnography of the schoolyards was undertaken, with a focus on how NAP and non-NAP students use the spaces. The ethnography involved the first author spending considerable time developing rapport with individual NAP classes and teachers during the times in which students ate their lunch inside the classroom, and then conducting observations in the playground space during lunchtimes. This phase was conducted over eight consecutive weeks. During this time, the first author observed in turn each of the main spaces of the yard in order to ascertain which students were using which spaces. Maps were used to depict where students played, and a charting system was devised in order to "count" students in terms of how many NAP and how many non-NAP students were using each space during the time the researcher was there.

Extensive field notes were also taken in order to record incidents which took place in an area whilst it was being observed. Such incidents would include what students were doing, any conversations held with students or teachers in the yard, and where exactly within each space students were (for example whether they were playing on the equipment, or running around the edge of the area). Interactions between NAP and non-NAP students were considered especially important. The observational notes were used to add richness and complexity to the quantitative charting system.

It is important to note here, as Thomson suggests, that whilst students were told who the first author was and what she was doing, this is not the same as obtaining informed consent. ${ }^{18}$ As the first author simply entered the classrooms and initiated conversations, and subsequently conducted observations in the yard, students at the schools were not given an opportunity to decline to participate. Of course, where a child seemed reluctant to speak to the first author during classroom conversations the first author would end the conversation and move on. However, and as Thomson states, students within school grounds are typically not in a position whereby they are able to refuse the attention of adults. ${ }^{19}$

Finally, a questionnaire was also developed to determine teacher opinions on school policies regarding the NAP, the school environment itself, and the use of space in the schoolyard. Questionnaires were provided to a total of eleven NAP teachers and twenty non-NAP teachers across both schools. (Responses were received from six of the NAP teachers and fifteen of the non-NAP teachers.) Teachers received an information sheet detailing the study and were required to sign a consent form. The questionnaire was a combination of questions with responses on Likert scales, together with open-ended questions in which teachers were given spaces 
to write their views. Teachers' views were also documented within the field notes as teachers at both schools frequently initiated conversations with the first author either in the yard or in the classroom during the ethnography phase of the study.

\section{The Use of Space}

The brief outline provided earlier regarding the current situation of refugees in Australia is a good illustration of the fact that the use of space, and claims to place, are never neutral: the spaces in which we move are highly regulated by social norms that determine how individuals can move. ${ }^{20}$ In many cases, spaces are centred around the values of dominant groups, and as such function to exclude people from marginalized groups, such as refugees, unless they are seen to "fit in" with the dominant culture. ${ }^{21}$

This is also reflected in the use of space by children in school playgrounds. Previous research has investigated the ways in which children's spaces are used by children themselves, and are managed and supervised by adults who are keen to control, protect, and socialize children. ${ }^{22}$ For example, research undertaken by Thomson found that children were active in their use of space within the school playground, despite strict controls by teachers monitoring the playground spaces during break times, meaning that children do have some degree of power over the spaces which they inhabit. ${ }^{23}$ However, refugee children entering such spaces may not have the power to resist, or indeed even be aware of, the norms already in place, or to shape spaces for themselves.

In Australia, intersections between the norms regulating refugee behaviour and children's behaviour can be seen in state primary schools that include a NAP for refugee and other migrant students. In fact, schools have frequently been identified within previous literature as spaces in which children are expected to behave according to strict social norms, ${ }^{24}$ and this may be especially the case in schools with children from a diverse range of backgrounds and which may actively police adherence to norms valued by the dominant group. For example, research suggests that the spaces in which children move are an important avenue of study as it is arguably within these spaces that the social norms of future generations will be formed. ${ }^{25}$ Furthermore, research suggests that the spaces in which children play represent important sites that contribute to children's social, cognitive, and physical development. ${ }^{26}$ Yet this contribution is never neutral: school spaces have the ability to change the ways in which children behave, such as by encouraging different forms of social interaction. ${ }^{27}$

As such, it is important to examine the ways in which children with refugee and other migrant backgrounds entering the education system are located in the school space in relation to school and other community norms. Indeed, the most salient divisions in primary schools with NAPs are arguably those between both newly arrived refugees and migrants from non-English speaking (NES) backgrounds, and children who have been in Australia for longer periods of time and who are fluent in English. Such divisions between children from these two backgrounds in the school space were seen in our study, where very few instances of interactions between NAP and non-NAP children were observed, with these two groups being largely segregated in the playground during play times. Even when the children were utilizing the same area (e.g., the same oval or the same play equipment), there were very few instances of actual interaction observed at either primary school.

The schools did differ, however, in terms of the opportunities for NAP students to find a space which they could lay claim to and play in as their own. At PPS, NAP children were only seen in a space of their own 2 per cent of the time, and were usually seen playing on the edges of the main play areas, and thus were not visible within the charting system (and its focus upon the main play areas within the school). So, for example, at PPS small groups of NAP students (typically two to four younger students) were often observed sitting and talking on the edge of the oval, or at the edge of playground areas, but rarely venturing into the area itself.

Conversely, at HPS, NAP students were seen more frequently (around 20 per cent of the time) playing in spaces on their own (such as the sandpit and the oval where NAP boys frequently played sport). The differences between the two schools regarding observations of the ability of NAP students to claim spaces of their own may be due in part to the fact that HPS has a much larger play area overall, with more distinct spaces than at PPS. This may have meant that there were more opportunities for NAP students to gather together in the same area away from non-NAP students, whilst at PPS NAP students were unable to claim any of the major spaces.

Interestly, despite the lack of observations of interaction between NAP and non-NAP students by the first author, teachers indicated that they felt that NAP and non-NAP students did interact together in the yard. For example, the majority of teachers (62 per cent at PPS and 54 per cent at HPS) perceived NAP and non-NAP students playing together across all main play areas at least sometimes, with 27 per cent at PPS and 21 per cent at HPS believing this happened frequently. This is in contrast to the observations of the first author who very rarely saw such interaction. In fact, across the whole eight weeks of observations students were only seen interacting across NAP/non-NAP boundaries four times. 
Whilst it is of course possible that integrated play does happen, and that it simply did not occur when the first author was conducting observations, this would seem unlikely given the amount of time spent in observations. A more likely answer is that teachers' perceptions of NAP and non-NAP students playing together were actually instances of both groups playing in the same area, but not together. Whilst the first author paid close attention to actual interactions between the two groups (as opposed to both simply being in the same area), teachers may not have noticed this difference. Whilst it is fair to acknowledge that teachers do not have the same luxury of time as does a researcher who is not charged with the task of keeping students safe and monitoring the play area, it is nonetheless significant that teachers perceived more interaction than perhaps does occur. For example, if teachers believe that interactions already occur, they may put less work into further encouraging positive interactions, thus allowing the potentially low current rates of interaction to continue.

Teachers were also instrumental in their control of the playground space, meaning that it was frequently the case that NAP students were unable to utilize the playground in ways determined by them. An anecdote from the field notes helps to illustrate this:

One of the NAP teachers tells me of two Anglo-Indian students in the school (a boy in yr 7 and a girl in grade 1) who are very new to Australia. The little girl has been crying all morning and refused to let her mother drop her off in her classroom and instead would only be dropped off at the office. I ask if there is any reason for why the little girl's behaviour has changed (they have been at the school since the start of term, and until now the little girl had not exhibited such behaviours). The teacher responds by telling me that "the little girl had been hanging out with her brother in the yard but they were recently told off by the yard duty teacher and told to play separately as generally within the school it is considered inappropriate for yr7s and yrls to be playing together." Later I see them in the yard sitting together by themselves finishing off their food.

Examples such as this highlight the complex ways in which school spaces are managed not only by students in their play behaviour, but also by teachers. ${ }^{28}$ In this instance, a yard duty teacher managed the ways in which two NAP students played on the basis of school rules established to govern all students, with little attention to the specific needs of these two students. So, for these siblings (and perhaps especially for the young girl), a possible need to play together is overridden by a school policy that prevents students playing together across classes. Similar findings come from Miller's research on refugee students' experiences in mainstream classes. ${ }^{29}$ One of her participants, a twentyyear-old boy who was placed in a year 10 class on the basis of his English language skills, was reprimanded for having a girlfriend in his year level. Again, this type of treatment of NAP students fails to recognize that such students will have specific needs that differ from those of non-NAP students (for whom school rules were likely primarily designed).

As such, our research found that, whilst it may be considered desirable that NAP and non-NAP students interact on an even basis within the school space, such interaction very rarely took place. In fact, power differentials seemed to work against NAP students in relation to both their ability to use the playground space with other children (as evidenced by the apparent difficulty they had in claiming spaces to play in) and with teachers (as seen in relation to sets of rules governing norms of behaviour which may not act to meet the needs of newly arrived students). One of the reasons provided for this lack of interaction and differences in power by both teachers at the schools, and previous literature in the area, was the fact that NAP students had low levels of English language skills. We turn now to a discussion of our findings in relation to this aspect of the "inclusion" of refugees and migrants.

\section{English as a Prerequisite for Inclusion}

Much of the published research advocates strongly for English language lessons as a central aspect of supporting the integration of NAP students into life in Australia. For example, Olliff and Couch state, "English represents the key to a possible future," and "the central role that English proficiency plays in determining successful integration of migrants into Australia society has been well documented." 30 These arguments were reflected in the statements about made about English on the questionnaires administered to teachers in the present study. Of the teachers who completed the questionnaire, over 75 per cent rated as significant (8 or higher on a scale where 10 represented "greatly") the impact of NAP students' level of English upon interactions between NAP and non-NAP students. Qualitative responses to this question also indicated that (primarily non-NAP) teachers at both schools felt that English was essential to the likelihood of interactions between NAP students and the broader society. Examples include: "NAP children need good English so they can smoothly transition" and "the more English they speak the easier it is for them to interact." One teacher also indicated that they felt that non-NAP students who initially had intentions to "buddy up" with NAP students did not persevere due to the language difference. As such, there appeared to be little reflexivity amongst teachers that integration must be a two-way street, with those in the position 
of relative power being willing to engage in dialogue about possible conflicting needs and agendas in relation to the terms on which inclusion is set.

Clearly, for us, there was a general assumption that English would facilitate the inclusion of refugees and other migrants. Whilst we would not argue per se against the role that language differences play in facilitating or inhibiting interaction, our concern here is that when an injunction is placed upon NAP students to learn English, there is little corollary injunction placed upon non-NAP students to engage with and learn from NAP students. Thus power relations which already exist in the broader community are reinforced within the school environment. This is discussed in an incisive paper by Norton Pierce on the relationship between investments in learning English and its perception as a form of cultural capital by non-English speaking (NES) migrants. Pierce suggests that the belief that, given the opportunity, NES migrants will easily and willingly learn English represents a failure to recognize that the learning of language always occurs on a particular social terrain in which those who already know the language hold considerable power. ${ }^{31}$

This was evident in one particular interaction observed between a NAP and a non-NAP student in the playground. During one lunch hour at Hills Primary School, a young girl from a non-NAP class was observed running with a ball that a young boy from a NAP class had been playing with. Running behind her was the boy himself, calling out "thank you, thank you" in an effort to claim back the ball from the girl who had stolen it from him. Ignoring him, the girl threw the ball to another non-NAP student who was in the area, but the ball hit a railing and bounced back to the child who originally had the ball, who grabbed it and ran off.

For some, this type of incident may seem either insignificant or as supporting the supposition that English language acquisition is vital to integration. However, we would suggest the need for a slightly more nuanced argument; namely that regardless of the practical utility of being able to speak up for oneself in a situation where one is in a marginal position, the ability to do so will always be moderated by the willingness of other people to listen. Again, this means that those students who are fluent in English are typically placed in positions of relative power when compared to NAP students. This argument echoes findings from an ethnographic study conducted by van Ausdale and Feagin, in which they observed the learning of racial categories and enactments of racism amongst nursery school-aged children. ${ }^{32}$ As they suggest, it is in mundane, everyday examples such as these that we see power differentials operate to the exclusion of marginalized groups of students. Of course, on one level, game-play amongst children often involves the claiming of another's territory or possessions, and this in and of itself does not necessarily constitute marginalization. But when we consider the broader picture of the ability (or otherwise) of a student to verbally resist this type of game play (other than saying "thank you"), the power struggles that shape language differences become more visible. It is such relations of power that we suggest need more attention within the school environment.

One area identified by some of the teachers as being able to realign (at least to some extent) such power relations was that of sport. Several teachers stated informally to the first author that they felt that sport was an area which brought NAP and non-NAP students together. It must be mentioned, however, that support for this was divided and some teachers stated in written responses on the questionnaire that lack of English impeded engagement in sports, as seen in comments such as: "NAP students don't feel confident enough to ask to join in a game, don't understand rules, so won't be able to effectively communicate to other members of a team if it is a team sport they are playing." This highlights an important difference between instrumental usage of English (where NAP students may have little capacity to engage in forms of interaction under testable circumstances that require English literacy), and comprehension of English-based cultural interactions (where NAP students may have considerable skills in other areas that facilitate interactions, such as sport). Certainly previous research on NAP students and social interaction has found that male NAP students are likely to engage in sports-based interactions that facilitate points of contact with non-NAP students, ${ }^{33}$ and that NAP students themselves point to the benefits of sports and other community activities to assist in the development of a sense of belonging. ${ }^{34}$ As such, sport could be considered an example of an area in which English language acquisition is able to occur in an arena that is less restricted by existing power relations that lead to a situation in which migrants are required to learn English before they are considered to have anything to contribute.

It is worth noting, however, that in this respect sport is an activity that may be more useful to male NAP students than it may be to female NAP students. As mentioned previously, the oval at HPS was a space that was at times claimed particularly by NAP boys as they participated in sports such as soccer; however, girls were not seen participating in sport to the same extent. This is reflective of previous studies of playground behaviour, in which it has been found that, irrespective of ethnicity, boys tend to engage more in team sports, whereas girls tend to participate in solitary activities in smaller groups. ${ }^{35}$ Thus it has been suggested that school spaces are "social settings particularly for boys." 36 This may have particular ramifications for schools with NAPs as boys 
will likely have more opportunity to come together as a large group across the NAP/non-NAP divide to play a team sport, whereas similar opportunities may not exist for girls.

\section{Implications for Schools}

Following from the discussion of these two different facets of the inclusion (or otherwise) of refugees and other migrants in the primary school environment, we would suggest that there is likely to be interplay between the primary focus upon low levels of English skills amongst NAP students (to the detriment of other skills which NES refugees and migrants may bring), and the lack of interaction between NAP and non-NAP students within the playground space. This interplay may be especially pronounced for refugee students who not only have low levels of English language skills but also may have little experience of prior education or indeed literacy in their own language. ${ }^{37}$ In the remainder of this paper we discuss the relationship between these two factors of English language skills and interaction, and suggest ways in which schools could work on building the bridges between NAP and non-NAP students.

Firstly, and whilst we recognize calls made in previous literature ${ }^{38}$ for education for NAP students that focuses on the backgrounds of these students (such as experiences of trauma in their home countries), we argue here for education which not only addresses this point, but which goes further in considering the ways in which education can be provided to NAP students through methods that recognize and account for unequal power relations between NAP (and especially refugee) students and non-NAP students. The negative representation of asylum seekers, refugees, and other migrants of "middle-eastern appearance" by many institutions in Australia, combined with the onus placed on NAP students to learn English in order to "integrate," leads to a situation in which many NAP students are under pressure to speak English not only in order to achieve good outcomes at school, but also to be perceived as fitting into the school environment, and thus the broader Australian society.

Secondly, the opinions of teachers will clearly have a significant impact on the ways in which refugee and other newly arrived migrant children are received into a primary school. Despite differing in their perceptions of the use of space from those observed by the first author, teachers' opinions at both schools were remarkably similar. For example, in casual discussions held with teachers by the first author, as well as in data obtained from the questionnaires, many teachers at both schools suggested that the segregation of NAP and non-NAP students in the playground was due to the fact that students in both NAP and non-NAP classes tended to play solely within their class groups, and that NAP children had low levels of English language skills. However, the first author observed NAP students at both PPS and HPS frequently playing across both class groups and language barriers.

The perceptions held by teachers in these areas means that there may be little incentive for schools to work to change these patterns of interaction. Interestingly, conversations with NAP teachers indicated that programs designed to encourage inter-class interaction and teach "social skills" were run at both schools during lunchtimes for NAP students to participate in, and this could explain the observation that NAP students played across class and language groups on a regular basis. However, similar programs were not run with the aim of building bridges across NAP and non-NAP classes (although HPS indicated it was about to start a course designed to encourage NAP/ non-NAP interaction). This lack of directed interaction between NAP and non-NAP students was also apparent in reports from NAP teachers, which indicated that they had difficulty organizing non-NAP teachers to take a student who was about to transition into a non-NAP class into their room for lessons such as art or sport. As such, cross-class interactions between NAP and non-NAP were reported as being difficult to organize and rare, meaning that the separation of NAP and nonNAP students extended beyond just the playground. Again, this could be a reflection of the fact that few teachers felt that there were issues with the ways in which students in the school interacted, and therefore did not feel there was any imperative to encourage such interaction.

It is important to consider that this lack of provision of opportunities for cross-class interactions on the part of teachers may be seen to model for students a separationist approach to NAP/non-NAP interactions in the playground. Given the importance of ensuring that refugee and other NAP students are not marginalized within school grounds, we would suggest that it is a responsibility of schools to ensure that positive interactions between NAP and nonNAP students do take place, and that NAP students are not isolated or marginalized within the school grounds. ${ }^{39}$ One way in which this outcome could be achieved would be to ensure that a number of classes which do not rely on English skills are shared by students from NAP and non-NAP classes. For example, several NAP teachers commented that they felt that their students could express themselves well through art, and that they really loved time spent painting or drawing. Having combined art classes could provide a point of contact between NAP and non-NAP students in which the skills of NAP students are highlighted. Combined classes also provide an opportunity for the school community to not simply "integrate" NAP students in a top-down approach which prioritizes "norms" 
of the playground space (set on the terms of the dominant group), but instead to allow refugees and other NAP students an opportunity to demonstrate their own wealth of knowledges, experiences, and skills. This would equally be the case for both shared art or music classes and shared sports activities, as discussed earlier.

In response to the two key issues we identify above (i.e., the potential overemphasis upon English language acquisiton and the role of teachers in either facilitating or inhibiting genuine inclusion), we now offer a number of suggestions that may assist schools to encourage interaction between newly arrived migrant and refugee students, and non-NAP students, and to engage with alternative methods of including students that do not rely on English language skills. Firstly, we suggest that all teachers need to be aware of differences which may exist for NAP students (especially newly arrived NAP students and those with experiences of forced migration) and to be prepared to adjust playground rules accordingly. Secondly, there is a need to ensure that school norms are not centred on those of its "mainstream" families, to the exclusion of refugee and immigrant communities. For example, there was some debate in both schools about the provision of prayer rooms (one of the schools in this study provided such a room whilst the other did not), and there was also discussion over what festivals and holidays are celebrated within the schools (i.e., Easter and Christmas being celebrated but not Ramadan or Eid). The priority accorded to dominant group traditions potentially functions to limit the ways in which NAP students perceive their ability to "own" the school space in the same way as non-NAP (and, more specifically, dominant group) students.

As such, a focus on recognizing the values, customs, skills, and knowledge brought by NAP students to the school, together with ensuring that the school environment supports the needs of students from all backgrounds, would also mean that NAP students may be more likely to see the school space as their own, rather than a space which they must attempt to "fit into." The rhetoric of "inclusion" and "integration" frequently referred to by teachers effectively places the onus on NAP students to conform to school customs and expectations, rather than creating an environment in which NAP students are able to shape the space to the same extent as non-NAP students. Acknowledging power relations between NAP and non-NAP students (particularly between refugee and non-refugee students), creating spaces within structured school time to encourage interaction between NAP and non-NAP students, and providing spaces which focus on the different knowledge of NAP students (and which will therefore also provide for the ongoing needs of students exiting the NAP into non-NAP classes) will all help to create an environment in which primary schools are not simply seen as solely the space of mainstream students into which NAP students must somehow find a way to "fit in," but rather as spaces shaped through the coming together of a range of differing groups.

In saying this, our suggestion here is of course not for a version of "melting pot" multiculturalism where power differentials are ignored. Instead, schools must acknowledge that despite their best efforts, dominant cultures will likely continue to dominate, to the disadvantage of marginalized people such as refugees and other migrants. As such, we recommend that schools be active in helping students to explore the cultural and social geographies of their schools in order to become more empowered to take a critical stance to their own education. ${ }^{40}$ To this end, we would suggest that there is a pressing need for educational approaches which afford both NAP and non-NAP students opportunities to understand the differential power relations they may encounter in the immediate school environment and the broader national as well as global context, which position those who speak fluent English as automatically belonging in Western nations such as Australia. One way of achieving this within an educational context is through the teaching of critical reflexivity regarding Australia's location in histories of colonization, particularly in relation to the countries from which NAP students come. Specific examples of this include Australia contributing troops to wars which have displaced many millions of people, current trade agreements which strongly reinforce the subordinated status of many countries, and legacies of empire building that continues to have significant effects both within Australia and abroad. ${ }^{41}$ This historical and current background functions to reinforce the power of non-NAP students, a fact that is ignored in much of the literature that places the responsibility for "assimilating," "integrating," or "belonging" firmly in the hands of refugees and migrants themselves.

In fact, an understanding of how these power relations are currently reinforced in schools is important in considering how a No Borders policy could be employed in practice, beginning with everyday instances of nationalism and exclusion. For a No Borders politics to be effective, it must first examine the understandings of "norms" of belonging in the nation-state, such as those seen and enacted within these two primary schools. In particular, this requires an understanding of the ways in which refugees are continually required to adhere to these supposed "norms" that are seen to be reflective of the values of the discrete nation-state, and which supposedly differentiate it from other nation-states. It is precisely these supposed "norms," seen in phrases such as "the Australian way of life," 42 which create a climate in which border control against those seen as "outsiders" is 
seen as justified, together with the ongoing requirements of "integration."

To conclude, creating a more just and less exclusionary society is the responsibility not only of schools but also of the broader Australian society. However, as an important point of contact between NAP and non-NAP children and their families, schools are in a unique and important position to begin to create a society in which refugees and other migrants are valued and seen to belong in their own right, rather than in which rights are associated with one's acquisition of national cultural capital by speaking English at a desired standard. Acknowledgment of these power relations and the responsibility Australia has towards marginalized groups of people would allow schools to consider how they are complicit with the injunction to produce docile citizens who do not critique existing power differentials.

\section{Notes}

1. See United Nations High Commissioner for Refugees, "Conflicts in Afghanistan and Somalia Fuel Increase in Asylum Seekers," press release, March 2009, online: http:// www.unhcr.org/news/NEWS/49c8a10d2.html.

2. For an example of this, see Paul Maley and Paige Taylor, "Kevin Rudd Faces Biggest Boat People Spike since Pacific Solution," The Australian, May 6, 2009, online: http://www. theaustralian.news.com.au/story/0,24897,25436120-601 ,00.html.

3. For example, the 2008-2009 Federal Budget included $\$ 120$ million for the detention of refugees. See the Refugee Council of Australia, The 2008-2009 Budget in Brief: What It Means for Refugees and Those Requiring Humanitarian Protection, online: http://www.refugeecouncil.org.au/ current/RCOA\%202008-09\%20Federal\%20Budget \%20Brief.pdf.

4. K. O'Doherty and A. Lecouteur, “'Asylum Seekers', 'Boat People' and 'Illegal Immigrants': Social Categorisation in the Media," Australian Journal of Psychology 59, no. 1 (2007): 1-12.

5. P. Mares, Borderline (Sydney: University of New South Wales Press, 2001).

6. T. Hayter, "No Borders: The Case against Immigration Control," Feminist Review 73 (2003): 6-18.

7. P. Cole, Philosophies of Exclusion: Liberal Political Theory and Immigration (Edinburgh: University of Edinburgh Press, 2000): 7.

8. Cynthia Wright, "Open the Borders! Nandita Sharma interviewed," New Socialist Magazine 38 (2002): 24-25; Hayter, 6-18.

9. M. Crock, B. Saul, and A. Dastyari, Future Seekers II: Refugees and Irregular Migration in Australia (Sydney: Federation Press, 2006); Mares.
10. G. Hage, White Nation: Fantasies of White Supremacy in a Multicultural Society (Annandale: Pluto Press Australia, 1998).

11. J. Pugliese, "The Locus of the Non: The Racial Fault-line 'of Middle-Eastern Appearance," Borderlands e-journal 2, no. 3 (2003), online: http://www.borderlandsejournal .adelaide.edu.au/vol2no3_2003/pugliese_non.htm.

12. Hage; C. Due and D. Riggs, "We Grew Here You Flew Here': Claims to 'Home' in the Cronulla Riots," Colloquy 16 (2008): 210-228.

13. L. Morrice, "Lifelong Learning and the Social Integration of Refugees in the UK: The Significance of Social Capital," International Journal of Lifelong Education 26, no. 2 (2007): 155-172.

14. C. Due, “'Who Are Strangers?': 'Absorbing' Sudanese Refugees into a White Australia," ACRAWSA e-journal 4, no. 1 (2008), online: http://www.acrawsa.org.au/ ejournalFiles/Volume\%204,\%20Number\%201,\%202008/ ClemenceDue.pdf

15. R. Sidhu and P. Christie, "Sticks and Stones Will Break My Bones-and Words Will Harm Them Too. Australia's Provision of Education for Asylum Seeker Children in Detention," Social Alternatives 21 (2002): 11-16.

16. J. Matthews, "Schooling and Settlement: Refugee Education in Australia," International Studies in Sociology of Education 18 (2008): 31-45.

17. Crock, Saul, and Dastyari.

18. S. Thomson, "Territorialising the Primary School Playground: Deconstructing the Geography of Playtime," Children's Geographies 3, no. 1 (2005): 63-78.

19. Ibid., 68.

20. S. Holloway and G. Valentine, "Sociology and the New Social Studies of Childhood," Sociology 34 (2000): 763-783.

21. D. Trudeau, "Politics of Belonging in the Construction of Landscapes: Place-making, Boundary-drawing and Exclusion," Cultural Geographies 13 (2006): 421-443.

22. Holloway and Valentine, 770-771.

23. See Thomson, 75-76.

24. Holloway and Valentine, 770-771.

25. Holloway and Valentine.

26. K. Malone and P. Tranter, "Children's Environmental Learning and the Use, Design and Management of Schoolgrounds," Children, Youth and Environments 13, no. 2 (2003).

27. Ibid.

28. See Thomson for a discussion of the ways in which student play is attempted to be managed by teachers.

29. J. Miller, "Language Use, Language and Social Interaction: Migrant Students in Australia," Research on Language and Social Interaction 33 (2000): 69-100.

30. L. Olliff and J. Couch, "Pathways and Pitfalls: The Journey of Refugee Young People in and around the Education System in Greater Dandenong, Victoria," Youth Studies Australia 24 (2005): 42-46. 
31. B. Norton Pierce, "Social Identity, Investment, and Language Learning," TESOL Quarterly 29 (1995): 9-30.

32. D. Van Ausdale and J. Feagin, The First R: How Children Learn Race and Racism (Lanham, MD: Rowman and Littlefield, 2001).

33. J. Brown, J. Miller, and J. Mitchell, "Interrupted Schooling and the Acquisition of Literacy: Experiences of Sudanese Refugees in Victorian Secondary Schools," Australian Journal of Language and Literacy 29 (2006): 150-162.

34. J. Miller, "Language, Membership and Social Identity" (paper presented at the Researching Education in New Times conference, Brisbane, Queensland, 1997).

35. P. Blatchford, E. Baines, and A. Pellegrini, "The Social Context of School Playground Games: Sex and Ethnic Differences, and Changes over Time after Entry to Junior School," British Journal of Developmental Psychology 21 (2003): 481-505.

36. Ibid., 498.

37. A. Woods, "Learning to Be Literate: Issues of Pedagogy for Recently Arrived Refugee Youth in Australia," Critical Inquiry in Language Studies 6, no. 1 (2009): 81-101; Miller, "Language Use."

38. Morrice, 165; R. Whiteman, "Welcoming the Stranger: A Qualitative Analysis of Teachers' Views Regarding the Integration of Refugee Pupils into Schools in Newcastle upon Tyne," Educational Studies 31, no. 4 (2005): 375-391.

39. See Morrice, 169, for a discussion of the responsibilities communities have to include refugees.

40. P. Kuriloff and M. Reichert, "Boys of Class, Boys of Colour: Negotiating the Academic and Social Geography of an Elite Independent School," Journal of Social Issues 59, no. 4 (2003): 751-769; Morrice, 169.

41. See Matthews for a discussion of the need to locate education in contexts of post-colonialism and global relations.
42. A practical example of these values and norms is seen in the Australian Citizenship Test that immigrants must pass before becoming citizens. Questions are related to Australia, including the "responsibilities and privileges of citizenship." For more information, see online: http://www.citizenship .gov.au/learn/cit_test/.

Clemence Due is a postgraduate student in the School of Psychology at the University of Adelaide. Her research is concerned with representations of belonging and race relations within Australia, and her PhD research examines such representations as they appear in the media with regard to minority racial groups living in Australia. Her research has also included the ways in which refugee and migrant children are included in the education system through New Arrivals Programs.

Damien Riggs, PhD, is a lecturer in social work at Flinders University. His research interests encompass critical race and whiteness studies, lesbian and gay psychology, and family and parenting studies. He has published widely in these areas and is the editor (with Barbara Baird) of The Racial Politics of Bodies, Nations and Knowledges (Cambridge Scholars Press, 2009) and the author of Priscilla, (White) Queen of the Desert: Queer Rights/Race Privilege (Peter Lang, 2006).

We acknowledge the sovereignty of the Kaurna people, the First Nations people upon whose land we live in Adelaide, South Australia. This research was funded by a Faculty of Health Sciences Small Research Grant. 